\title{
A General Survey of Radon Concentration in Water from Rivers in Gauteng, South Africa Using a Solid-State $\alpha$-Detector
}

Masevhe $\mathrm{L}^{1}$, Mavunda RD ${ }^{1,2^{*}}$ and Connell $\mathbf{S}^{1}$

${ }^{1}$ University of Johannesburg (UJ), Johannesburg, South Africa

${ }^{2}$ Radiation Protection Training Centre (RPTC), South African Nuclear Energy Corporation (NECSA), Pelindaba, Britz, South Africa

\begin{abstract}
In view of the geological setup and the long-standing mining history of the Gauteng Province, South Africa, it is expected that the mine dumps around the gold mines could contribute to a significant radium $\left({ }^{226} \mathrm{Ra}\right)$ concentration in water in Gauteng Province. Radium decays to its daughter radioisotope radon $\left({ }^{222} R n\right)$ which is a potential source of radiation exposure to the general public. Radon-222 easily escapes from surface of mineral grains and it becomes dissolved in ground water, rivers and dams which are ultimately used by the public. The research study was carried out to determine the effective dose $(m S v)$ to the general public from radioactive $\left({ }^{222} R n\right)$ in the water from 25 rivers and tributaries in the surrounding areas of Krugersdorp, Johannesburg, Pretoria and Vaal regions.

Water samples were collected from the rivers and analysed in the laboratory at Necsa in Pretoria. An $\alpha$ - spectrometry analysis using a solid-state alpha detector (RAD-7) was optimized to measure $\left({ }^{222} R n\right)$ in the water by counting $\alpha$ particles emitted by ${ }^{218} \mathrm{Po}$ and ${ }^{214} \mathrm{Po}$ in secular equilibrium with their parent, $\left({ }^{222} \mathrm{Rn}\right)$.

The measured ( $\left.{ }^{222} \mathrm{Rn}\right)$ concentrations ranged from $1.4 \times 10^{-1}$ to $3.56 \mathrm{~Bq} . \mathrm{I}^{-1}$ with an average of $1.43 \pm 4.3 \times 10^{-1} \mathrm{~Bq} . \mathrm{I}^{\prime}$ 1 . The average annual effective dose was found to be $4 \times 10^{-3} \mu \mathrm{Sv}$. The study showed that ${ }^{222} R a$ concentration in river water from Gauteng is lower than international acceptable limits cited in the United States Environmental Protection Agency and the World Health Organisation of $1.11 \times 10^{-1} \mathrm{~Bq} . \mathrm{I}^{-1}$ and $1.0 \times 10^{-2} \mathrm{~Bq} . \mathrm{I}^{-1}$ respectively. The average effective dose is negligible (about $0.32 \%$ ) as compared to the worldwide average annual effective dose from inhaled ${ }^{222} R n$ of 1.26 $m S v$. Hence, the effective dose of $4 \times 10^{-3} \mu S v$ does not pose any health threat to the general public that use water from Gauteng Rivers.
\end{abstract}

Keywords: Radon in water; Radon; $\alpha$-Spectrometry; Mining

\section{Introduction}

The exposure to excessive radiation from radon due to its radioactivity has drawn the attention of many scientists all over the world, particularly in the last decade [1]. Their main research goal has been the evaluation of the indoor radon concentration essentially because radon is the most relevant source of the major mean public exposure to ionizing radiation [2]. It is often the single largest contributor to an individual's background radiation dose, and is the most variable from one location to another due to different geological setup [3]. Radon is a progeny of ${ }^{226} R a$ which is a member of ${ }^{238} U$ decay chain and it can enter the human body through ingestion when eating food or drinking water contaminated with radon or by breathing in radon-filled air [1].

The exposure due to inhalation of radon and its progeny is the highest of the natural radionuclide to which human beings in the general environment are exposed to [4]. During the ingestion of radonrich water, radon progeny can be absorbed and then energy is either deposited in the surrounding tissues [5] or be transferred through the blood vessels to other organs where it causes chromosomal aberrations which in turn increase the chance of cancer incidence [6]. Further epidemiological studies and analysis in radon confirmed again a clear evidence that lung cancer can be caused by exposure to radon gas [7-9].

In the past, radon in water was measured by counting $\alpha$ - particles emitted by its progeny, ${ }^{218} P o$ and ${ }^{214} P o[10-12]$. Special attention is needed when sampling and handling radon-rich water because it escapes easily. Therefore, glass bottles with caps equipped with rubber or Teflon septum to prevent radon leakage were used to collect and store water samples from the rivers [13]. The time between collection and analysis was carefully considered for the calculation of decay correction for each sample to avoid radon concentration underestimation. Higher concentration of radon can cause health problems if it is inhaled or ingested, hence the measurement in the study was of special interest to mankind. The purpose of the study was to measure radon concentration and dosage in the natural water using solid state alpha detector.

\section{Experimental Technique}

\section{Alpha-spectrometry using RAD-7 detector}

Figure 1 represents experimental set-up using grab sample and radon-in-air monitor, RAD-7 detector. The detector is a highly versatile instrument used to measure radon in real-time and it applies the $\alpha$ spectrometry process [14]. A major advantage of the RAD-7 detector is its high sensitivity and capability to achieve detection limits as low as $1 \mathrm{mBq}$ per sample. RAD-7 detector uses the $\mathrm{RAD}-\mathrm{H}_{2} \mathrm{O}$ accessory which enabled it to measure radon in water over a concentration range from less than $10 \rho \mathrm{Ci}^{-l^{-1}} 3.7 \times 10^{-1} \mathrm{~Bq} . \mathrm{l}^{-1}$ to greater than $4.0 \times 10^{-5} \rho \mathrm{Ci} . \mathrm{l}^{-1}$ $\left(1.48 \times 10^{4} \mathrm{~Bq} . \mathrm{l}^{-1}\right)[15]$ in a short time. This technique employs closedloop concept, consisting of four components, the RAD-7, tube desiccant, water vial aerator and connection tubes as shown in Figure 1.

\section{Internal cell of RAD-7}

The internal cell of RAD-7 is a dome of volume of 0.7 litres [15]. An

*Corresponding author: Mavunda RD, Radiation Protection Training Centre (RPTC), South African Nuclear Energy Corporation (NECSA), Pelindaba, Britz, South Africa, Tel: +27762864786; E-mail: mavundard@gmail.com

Received April 29, 2017; Accepted May 13, 2017; Published June 03, 2017

Citation: Masevhe L, Mavunda RD, Connell S (2017) A General Survey of Radon Concentration in Water from Rivers in Gauteng, South Africa Using a Solid-State a-Detector. J Environ Anal Toxicol 7: 472. doi: 10.4172/2161-0525.1000472

Copyright: @ 2017 Masevhe L, et al. This is an open-access article distributed under the terms of the Creative Commons Attribution License, which permits unrestricted use, distribution, and reproduction in any medium, provided the original author and source are credited. 


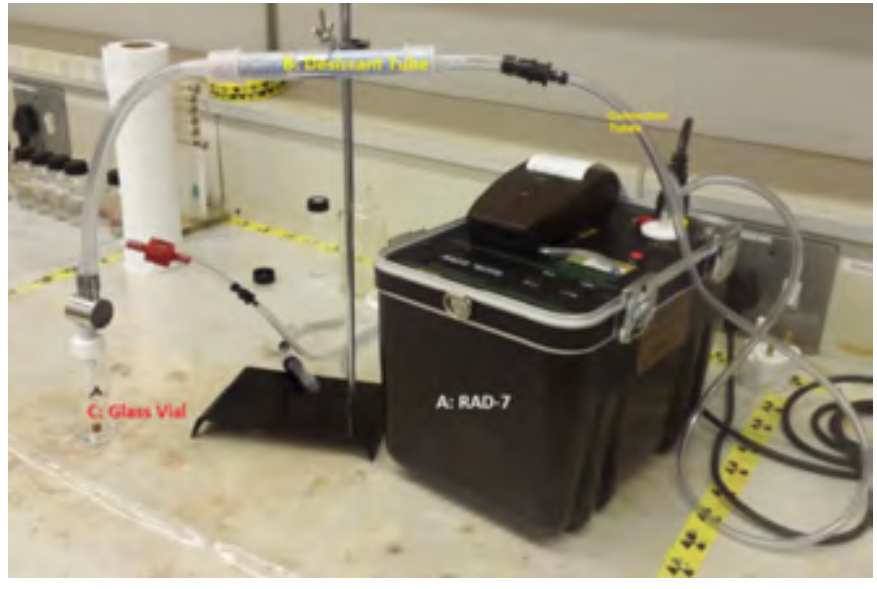

Figure 1: RAD-7 set-up at Necsa's Radio-analysis laboratory.

ion-implanted, planar and Silicon alpha detector is at the centre of the hemisphere and its measurement chamber is represented in Figure 2a. The high voltage power circuit charges the inside conductor to a potential of $2000-2500 \mathrm{~V}$, creating an electric field throughout the internal cell [15]. The radon-rich air is sucked inside and it decays into the positive ions of ${ }^{218} \mathrm{Po}+\mathrm{T}_{1 / 2}=3.05 \mathrm{~min}$; $\alpha$-energy $\left.=6.00 \mathrm{MeV}\right)$ and ${ }^{214} \mathrm{Po}+\left(\mathrm{T}_{1 / 2}=164\right.$ $\mu s ; \alpha$-energy $=7.67 \mathrm{MeV}$ ), which are propelled by the electric field and be deposited onto the detector [14].

When the radon progeny, deposited on the surface of the detector, decay, they emit $\alpha$ - particles of characteristic energy is directly measured by the solid-state detector. The microprocessor in the RAD-7 picks up the signal and stores it according to the energy of the particle [15]. The accumulation of many signals results in a spectrum as shown in Figure 2b.

\section{Annual effective dose}

The annual effective dose, $D_{a}$ due to the ingestion of radon from water, was calculated according to equation [14]

$$
D_{a}=C R n \times C_{f} \times A C_{\mathrm{H}_{2} \mathrm{O}}
$$

Where $\mathrm{D}_{\alpha}\left(m S v \cdot a^{-1}\right)$ is the committed effective dose, $\mathrm{C}_{\mathrm{Rn}}\left(B q . l^{-1}\right)$ is the radon concentration in water, $\mathrm{C}_{f}\left(m S v . B q^{-1}\right)$ is a conversion factor, equal to $1 \times 10^{-8} \mathrm{~Sv} . B q^{-1}$; and $A C_{\mathrm{H}_{2}}\left(\mathrm{l} \cdot \mathrm{a}^{-1}\right)$ is the annual water consumption by an adult [14]. The consumption for an adult per annum was taken to be 730 1. The United Nations Scientific Committee on the Effects of Atomic Radiation (UNSCEAR) estimated that the committed effective dose from the ingestion of radon in water is $1.0 \times 10^{2} n S v . B q^{-1}$ for an adult, $7.0 \times 10^{1} n S v$. $B q^{-1}$ for a child and $2.0 \times 10^{1} n S v$. $B q^{-1}$ for an infant.

Table 1 embodies the proposed guidelines on radiation dose in drinking water according to the Department of Water Affairs and Forestry (DWAF) [16,17]. The guidelines have taken into consideration dose ranges per annum $\left(\mu S v \cdot a^{-1}\right)$, health effects and intervention time for the protection of the public from anthropogenic sources of radiation. The basis for the colour-coded classification system was chosen to be in line with the approach used in the joint Assessment Guide by the Department of Health $(\mathrm{DoH})$, and the Water Research Commission (WRC) [17].

\section{Methodology}

In the current study, radon concentration in water from Gauteng rivers (see Figure 3) was measured in the laboratory at the Radiation

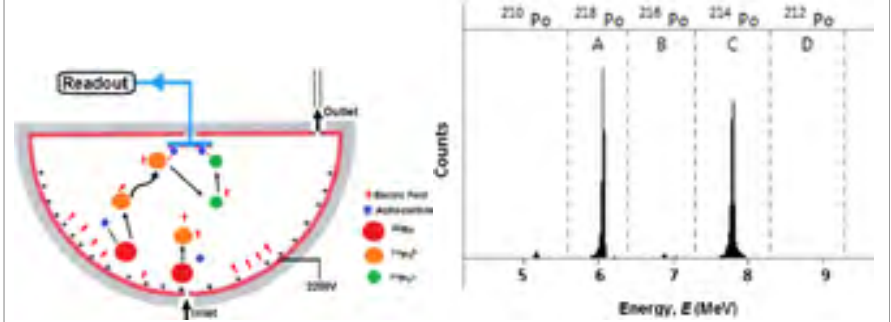

Figure 2: Measuring chamber of the RAD-7 and the accumulation spectrum. (a) Internal cell of the RAD-7 detector; (b) Spectrum of ${ }^{218} \mathrm{Po}$ and ${ }^{214} \mathrm{Po}$ after 3 hours, respectively [14].
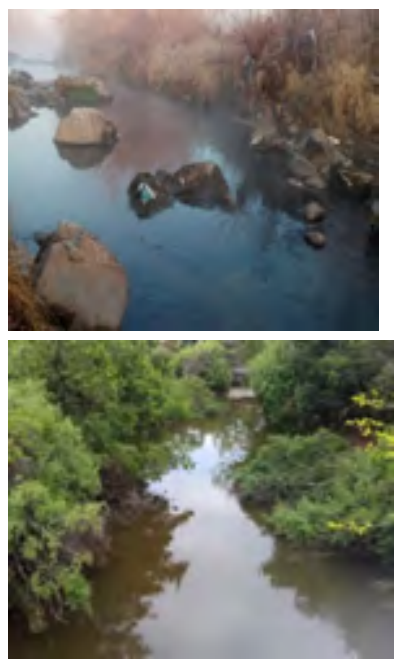

Figure 3: Sampling sites in (a) Skinnerspruit - Pretoria West and (b) Sesmylspruit - Irene.

Protection Training Centre (RPTC), Necsa Learning Academy (NLA) division. Figure 4 is the schematic view of the experimental setup with the arrows representing the air flow's path. In this system, air was bubbled through a $250 \mathrm{ml}$ vial with a water sample for five minutes, for degassing process. The ${ }^{222} R n$ diffusing from the water sample continuously circulated through a close-loop to establish equilibrium between the radon in water and in air. The final concentration of radon in the two phases was described by Henry's law, which states that the mass of a gas which is dissolved into a solution is directly proportional to the partial pressure of that gas above the solution [18-22].

\section{Results}

The results of experimental radon measurement showed that radon concentration varied from one location to another as shown in Figure 5, with the lowest and highest recorded values of $1.3 \times 10^{-1} \pm$ $8.0 \times 10^{-2}$ Bq..$^{-1}$ and $2.87 \pm 3.1 \times 10^{-1}$ Bq..$^{-1}$ for Vaal River and Moreleta, respectively. Meteorological parameters, relative humidity $(\mathrm{RH})$ and internal temperature $\left(\mathrm{T}_{\text {int }}\right)$ of the detector, which have an influence on radon release from water, were also measured as shown in columns 3 and 4 in Table 2 respectively. The radiation doses from different region of Gauteng rivers were classified by colour-codes in Table 2 according to reference Table 1 which shows that there is no need for any intervention because there were no health effects observed. The average dosage found was $7.8 \times 10^{-3} \mathrm{mSv} \cdot \mathrm{a}^{-1}$, which is coloured blue referring to Table 1 for an ideal water quality.

Radon concentration from rivers increase downstream. In Figure 6a radon concentration in Bruma Lake was $3.9 \times 10^{-1} \pm 2.1 \times 10^{-1} \mathrm{~Bq} . \mathrm{l}^{-1}$ 
Citation: Masevhe L, Mavunda RD, Connell S (2017) A General Survey of Radon Concentration in Water from Rivers in Gauteng, South Africa Using a Solid-State a-Detector. J Environ Anal Toxicol 7: 472. doi: 10.4172/2161-0525.1000472

Page 3 of 5

\begin{tabular}{|c|c|c|c|}
\hline Dose class & Colour & $\begin{array}{c}\text { Dose range } \\
\left(\boldsymbol{m} \boldsymbol{S} \boldsymbol{v} \cdot \mathbf{a}^{-1}\right)\end{array}$ & $\begin{array}{c}\text { Health effects } \\
\text { Intervention indicators time frame }\end{array}$ \\
\hline Class 0, (ideal quality) & & $0.01-0.1$ & No observable health effects \\
\hline Class 1, (good quality) & $>0.1-1$ & $\begin{array}{c}\text { No observable health effects } \\
\text { Intervention not applicable }\end{array}$ & $\begin{array}{c}\text { No intervention required, but ALARA principle } \\
\text { applies }\end{array}$ \\
\hline Class 2, (marginal quality) & $>1-10$ & Small increase in cancer mortality risk \\
\hline Class 3, (poor quality) & $>10-100$ & $\begin{array}{c}\text { Cancer risk statistically detectable in very large } \\
\text { population groups }\end{array}$ & Intervention required within 1 year \\
\hline Class 4, (unacceptable quality) & $>100$ & Health effects clinically detectable \\
\hline
\end{tabular}

Table 1: Radiation dose ranges for drinking water with health effects and intervention time frames indicators [17].

\begin{tabular}{|c|c|c|c|c|c|c|}
\hline Sampling Site & No. of Samples & RH (\%) & $\begin{array}{c}\mathbf{T}_{\text {int }} \\
\left({ }^{\circ} \mathrm{C}\right)\end{array}$ & ${ }^{222} \mathrm{Rn}_{\mathrm{Av} .}\left(\mathrm{Bq} \cdot \mathrm{L}^{-1}\right)$ & $\mathbf{A E} \mathbf{D}_{\text {ing }}\left(\mathbf{m S v} \cdot \mathbf{a}^{-1}\right)$ & Colour code \\
\hline Apies & 2 & 16 & 20.3 & $1.18 \pm 0.18$ & $1.95 \times 10^{-2}$ & \\
\hline Bloubankspruit & 2 & 14.7 & 30.4 & $0.61 \pm 0.21$ & $9.4 \times 10^{-3}$ & \\
\hline Eco Park & 1 & 23.4 & 26.6 & $0.55 \pm 0.10$ & $3.4 \times 10^{-3}$ & \\
\hline Edendalspruit & 2 & 20 & 20.3 & $1.73 \pm 0.22$ & $6.2 \times 10^{-3}$ & \\
\hline Hannops River & 4 & 24 & 21.93 & $2.67 \pm 0.23$ & $8.1 \times 10^{-3}$ & \\
\hline Jukskei River & 13 & 22.04 & 23.03 & $1.29 \pm 0.16$ & $2.09 \times 10^{-2}$ & \\
\hline Klip River & 2 & 22.9 & 24.9 & $0.46 \pm 0.11$ & $1.07 \times 10^{-2}$ & \\
\hline Magaliesriver & 1 & 13.5 & 29.0 & $0.84 \pm 0.21$ & $3.9 \times 10^{-3}$ & \\
\hline Moganwe & 1 & 22.5 & 26.3 & $1.11 \pm 0.44$ & $1.25 \times 10^{-2}$ & \\
\hline Moreleta & 2 & 21 & 20.2 & $2.87 \pm 0.31$ & $7.8 \times 10^{-3}$ & \\
\hline Muldersdrift Se Loop & 2 & 17.8 & 30.9 & $1.07 \pm 0.20$ & $1.17 \times 10^{-2}$ & \\
\hline Olifantspruit & 1 & 26.4 & 24.2 & $0.54 \pm 0.10$ & $2.6 \times 10^{-3}$ & \\
\hline Pienaarsriver & 2 & 19.4 & 22.2 & $1.71 \pm 0.24$ & $3.7 \times 10^{-3}$ & \\
\hline Rietspruit (Midrand) & 2 & 29.7 & 20.7 & $1.07 \pm 0.14$ & $6.4 \times 10^{-3}$ & \\
\hline Sesmylspruit & 2 & 22 & 18.5 & $1.60 \pm 0.10$ & $9.0 \times 10^{-4}$ & \\
\hline Skinnerspruit & 1 & 23 & 23.6 & $0.36 \pm 0.20$ & $9.2 \times 10^{-3}$ & \\
\hline Swartspruit & 1 & 23.5 & 22.0 & $0.50 \pm 0.27$ & $2.7 \times 10^{-3}$ & \\
\hline Swartbooispruit & 1 & 28.8 & 24.3 & $0.88 \pm 0.13$ & $1.3 \times 10^{-3}$ & \\
\hline Vaal River & 4 & 21.23 & 26.78 & $0.13 \pm 0.08$ & $1.95 \times 10^{-2}$ & \\
\hline Walkerspruit & 2 & 21.5 & 21.75 & $1.14 \pm 0.74$ & $9.4 \times 10^{-3}$ & \\
\hline Wonderfontein & 1 & 19.9 & 27.3 & $0.37 \pm 0.14$ & $3.4 \times 10^{-3}$ & \\
\hline Zwavelpoortspruit & 1 & 23.5 & 25.4 & $1.82 \pm 0.19$ & $6.2 \times 10^{-3}$ & \\
\hline
\end{tabular}

Table 2: Results of ${ }^{222} R n$ concentrations and the average annual effective dose due to the ingestion $\left(A E D_{\text {ing }}\right)$ of radon in river water samples. The confidence level ( $\left.95 \%\right)$ was $32 \%$.

and increase to $1.43 \pm 4.1 \times 10^{-1} \mathrm{~Bq} . \mathrm{l}^{-1}$ in Kyalami Bridge. Similar trend was observed in Figure $6 \mathrm{~b}$ for Hannops and Walkerspruit Rivers. This observation was an indicative of the accumulation of radon in the water and that from one location to another.

Table 3 presents the measurement results conducted for commercial water (bottled water) to determine the level of radon concentration and its dosage. Three different products were considered as indicated and the results show that the level of radon concentration is lower than most of the samples from the rivers in Table 2.

\section{Discussion}

The results of the current study indicated that the activity concentrations of ${ }^{222} \mathrm{Ra}$ in river water in Gauteng is lower than the international levels ranging from $1.4 \times 10^{-1}$ to $3.6 \times \mathrm{Bq} . \mathrm{l}^{-1}$ with an overall average of $1.43 \pm 4.3 \times 10^{-1} \mathrm{~Bq} . l^{-1}$. Radionuclide specific concentration complied with WHO guidance levels of $1.0 \times 10^{2} \mathrm{~Bq} . \mathrm{l}^{-1}$ for ${ }^{222} \mathrm{Ra}$ [18]. The USEPA, USA has proposed a radon limit in water of $1.11 \times B q . l^{-1}$ whereas Poland and Czech recommended contaminant levels over 7.5 $\times 10^{-1} \mathrm{~Bq} . \mathrm{l}^{-1}$ and $5.0 \times 10^{1} \mathrm{~Bq} . \mathrm{l}^{-1}$ respectively [19].

It was observed that in the Jukskei, Hennop and Walkerspruit rivers radon concentration increases downstream (see Figure 6a and 6b) with weighted mean activity concentration of ${ }^{222} \mathrm{Ra}$ of $9.9 \times 10^{1}$ $B q . l^{-1}$. The results further showed that radon concentrations differ from one location to the other as shown in Figure 5. The difference in concentration might be due to the geological nature of rocks floor of the river. All the analysed samples in the current study revealed that radon concentration in water was below the international recommendations.

When radon contaminated water is ingested, radon gas diffuses into the stomach wall and irradiate it. The equivalent dose to the stomach of $0.1 \mathrm{mSv} \cdot B q^{-1}$ was adopted by UNSCEAR (1977) and also supported by Kendall et al. [20]. General radon annual effective dose in Table 2 ranged from $1.01 \times 10^{-3}$ to $9.56 \times 10^{-3} \mathrm{mSv}^{-a^{-1}}$ with an average of 4.03 $\times 10^{-3} \mathrm{mSv}^{-1} \mathrm{a}^{-1}$. These doses in comparison with average effective dose from all natural sources $2.4 \mathrm{mSv}$ [21] are negligible (about $0.167 \%$ ). This value showed that consumption of water from these rivers in and around Gauteng Province in South Africa, radon concentration will be in the stochastic range, thus the probability of inducing cancer is negligible.

\section{Conclusions}

The usage of water from rivers in Gauteng was found to have no health threat as far as radon dosage is concerned since the dose levels are lower than the international safety levels. This survey was a step 
Citation: Masevhe L, Mavunda RD, Connell S (2017) A General Survey of Radon Concentration in Water from Rivers in Gauteng, South Africa Using a Solid-State $\alpha$-Detector. J Environ Anal Toxicol 7: 472. doi: 10.4172/2161-0525.1000472

Page 4 of 5

\begin{tabular}{|c|c|c|c|c|}
\hline Sample No & Description of water & $\mathbf{C}_{\text {water }}$ (mBq/l) & $\mathbf{C}_{\text {Actual }}$ (mBq/l) $_{\text {Water }} \mathbf{m S v . a}^{-1}$ & $0.72 \pm 0.37$ \\
\hline 1 & Valpre & $0.65 \pm 0.36$ & $2.63 \pm 1.35$ \\
\hline 3 & Distilled & $0.27 \pm 0.29$ & $0.49 \pm 0.30$ \\
\hline
\end{tabular}

Table 3: General Survey of Radon Concentration from Commercial (Bottled) Water.

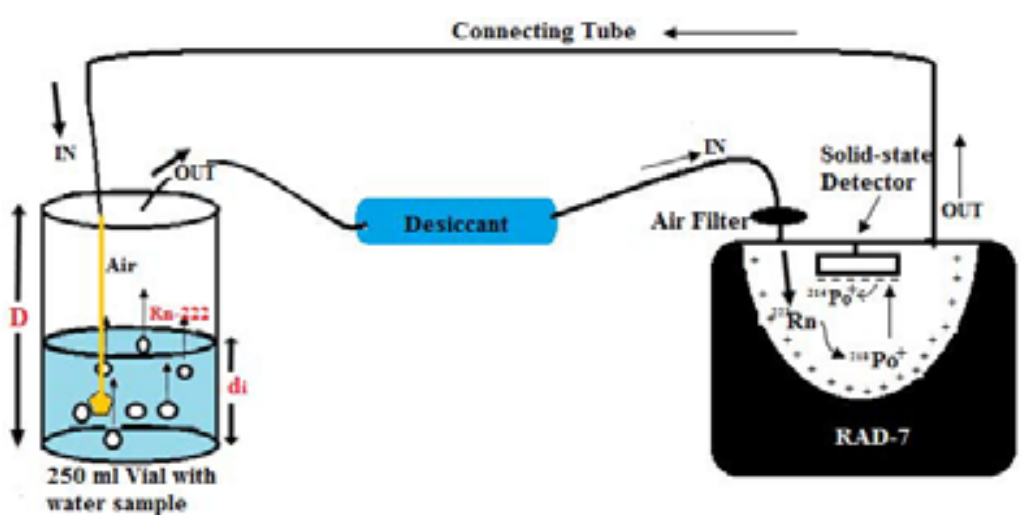

Figure 4: Schematic representation of the experimental setup.

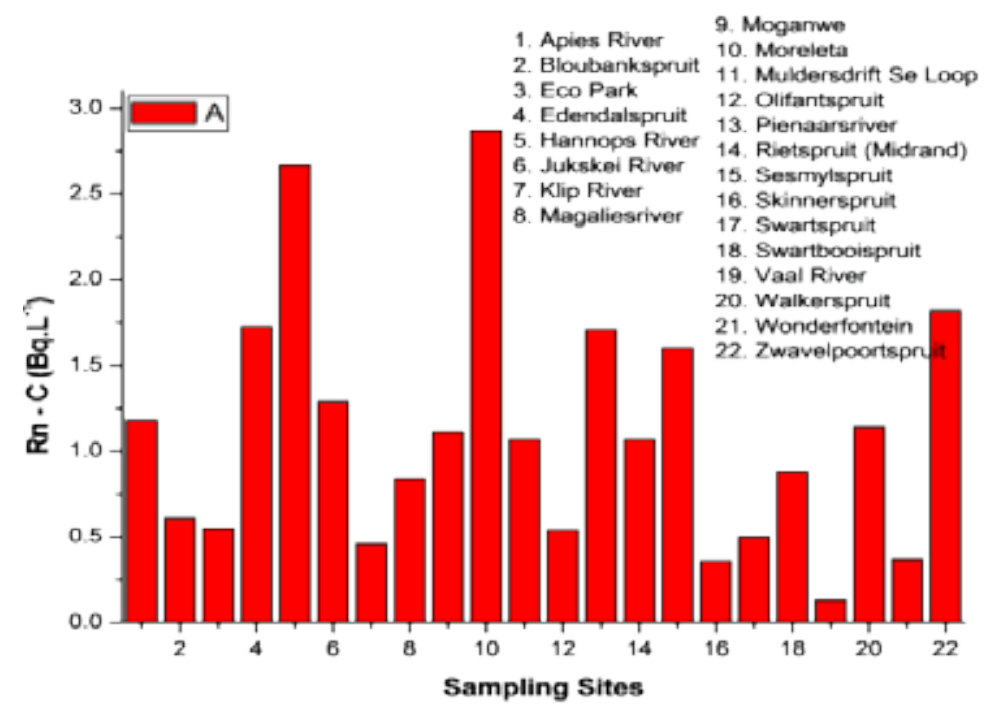

Figure 5: Radon Concentration Survey in Water from Gauteng Rivers.

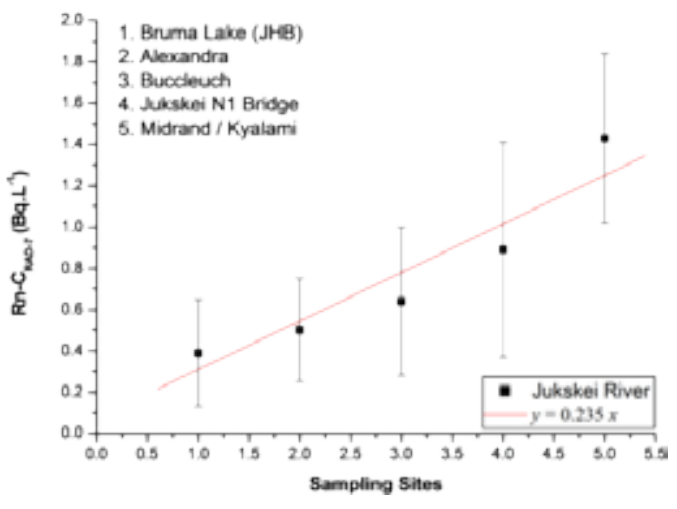

(a)

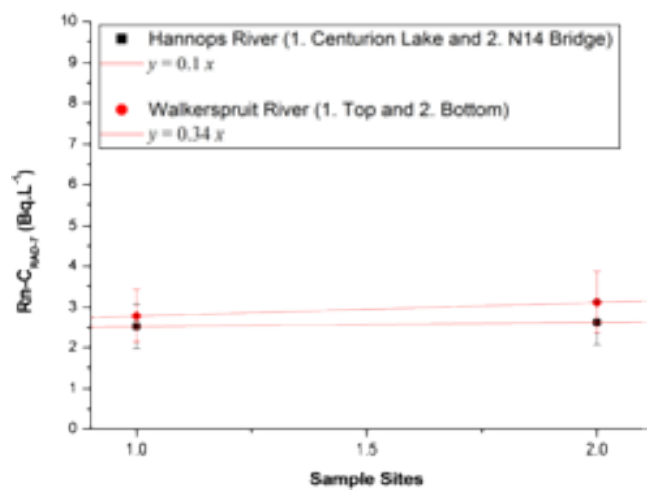

(b)

Figure 6: Radon activity concentration at different sampling spots in the (a) Jukskei, and (b) Hannops and Walkerspruit rivers. 
Citation: Masevhe L, Mavunda RD, Connell S (2017) A General Survey of Radon Concentration in Water from Rivers in Gauteng, South Africa Using a Solid-State $\alpha$-Detector. J Environ Anal Toxicol 7: 472. doi: 10.4172/2161-0525.1000472

Page 5 of 5

towards more and thorough studies considering the physical and chemical properties of radon gas. More work is yet to be done for the development of reliable radiological map for radon concentration in other provinces in South Africa. Since radon travelled from its point of origin (i.e., rocks and soil), it is important to include radon in the soil around the water sampling sites in rivers.

\section{References}

1. Lee JM, Kim G (2006) A simple and rapid method for analysing radon in coastal and ground waters using a radon-in-air monitor. Journal of Environmental Radioactivity 89: 219-228.

2. Hasan AK, Subber AR, Shaltakh AR (2011) Measurement of Radon Concentration in Soil Gas using RAD7 in the Environs of Al-Ashraf City-Iraq. Advances in Applied Science Research Palagia Research Library 2: 273-278.

3. Roper WL (1990) Agency for Toxic Substances and Diseases Registry. Toxicological Profile for Radon. US Public Health.

4. Singh S, Kumar A, Bajwa BS, Mahajan S, Kumar V, et al. (2010) Radon monitoring in soil gas and groundwater for earthquake prediction studies in North West Himalayas, India. Terr Atmos Ocean Sci 21: 685-695.

5. Khan HA (1991) Radon: a friend or a foe?. International Journal of Radiation Applications and Instrumentation. Part D. Nuclear Tracks and Radiation Measurements 19: 353-362.

6. Abo-Elmagd M, Metwally SM, El-Fiki SA, Eissa HM, Salama E (2006) Passive and active measurements of radon-related parameters inside ancient Egyptian tombs in Luxor. Science Direct. Radiation Measurements 42: 116-120.

7. Lubin JH (2003) Studies of radon and lung cancer in North America and China. Radiat Prot Dosimetry 104: 315-319.

8. Darby S, Hill D, Auvinen A, Barros-Dios JM, Baysson H (2005) Radon in homes and risk of lung cancer: collaborative analysis of individual data from 13 European case-control studies. BMJ 330: 223-228.

9. Krewski D, Lubin JH, Zielinski JM, Alavanja M, Catalan VS, et al. (2005) Residential radon and risk of lung cancer: a combined analysis of 7 North American case-control studies. Epidemiology 16: 137-45.
10. Zeeb H, Shannoun F (2009) WHO handbook on indoor radon: a public health perspective. WHO Press.

11. Bonotto DM, Mello CB (2006) A combined method for evaluating radon progeny in waters and its use at Guarani aquifer, Sao Paulo State, Brazil. J Environ Radioact. 69: 21-35.

12. Bertin C, Bourg AC (1994) Radon-222 and chloride as natural tracers of the infiltration of river water into an alluvial aquifer in which there is significant river/ groundwater mixing. Environ Sci and Tech. 28: 794-798.

13. Saito M (1982) Correction for loss of radon-222 in water sample caused by the use of a polythylene bottle. Radioisotopes 32: 109-112.

14. RAD-7, RAD- $\mathrm{H}_{2} \mathrm{O}$ (2012) Radon in Water Assessory. Durridge Co., USA.

15. Cho JS, Ahn JK, Kim HC, Lee DW (2004) Radon concentrations in groundwater in Busan measured with a liquid scintillation counter method. J Environ Radioact 75: 105-112.

16. Schubert $M$, Buerkin W, Pena P, Lopez AE, Balcázar M (2006) On-site determination of the radon concentration in water samples: Methodical background and results from laboratory studies and a field-scale test. Radiation Measurements 41: 492-497.

17. DWAF, NRMP (2003) Report on the Radioactivity Monitoring Programme in the Klip River Catchment. Report No. N000000REQ0403. p: 33.

18. WHO (2004) Guidelines for drinking water quality. 3rd edn. Geneva: World Health Organisation.

19. Burnett WC, Dulaiova $H$ (2003) Estimating the dynamics of groundwater input into the coastal zone via continuous radon-222 measurements. J Environ Radioact 86: 337-353.

20. UNSCEAR (1997) Sources and effects of ionizing radiation: Report to the general assembly. Annex B. Natural Sources of radiation. New York: United Nations.

21. Erees FS, Aytas S, Sac MM, Yener G, Salk M (2007) Radon concentrations in thermal-waters related to seismic events along faults in the Denizli Basin, Western Turkey. Radiation Measurements 42: 80-86.

22. Negarestani A, Hashemipoor $\mathrm{RH}$, Noori $\mathrm{H}$, Shahpasandzadeh $M$, Naseri $F$ et al. (2009) Modelling of the radon exhalation from water to air by a hybrid electrical circuit for earth quake prediction. Geophysical Research Abstracts 11: 1165. 